\title{
KINERJA KEUANGAN DALAM MEMPREDIKSI FINANCIAL DISTRESS
}

\author{
Nurhidayah \\ Dosen STIE Asia Malang \\ Fitriyatur Rizqiyah \\ Alumni STIE Asia Malang
}

\section{ABSTRAK}

Penelitian ini bertujuan untuk mengetahui prediksi financial distress pada industri manufaktur sub sektor makanan dan minuman yang terdaftar di Bursa Efek Indonesia. Periode penelitian yang digunakan adalah tahun 2011-2015. Dalam penelitian ini menggunakan indikator likuiditas, profitabilitas, inflasi,dan kurs. Populasi penelitian meliputi seluruh sub sektor makanan dan minuman yang terdaftar di Bursa Efek Indonesia periode 2011-2015. Pemilihan sampel menggunakan sampel jenuh. Metode analisis data yang digunakan adalah analisis regresi logistik.

Hasil penelitian menunjukkan bahwa current ratio, return on investment dan net profit margin, dan tingkat inflasi merupakan variabel yang signifikan dalam memprediksi financial distress, sementara kurs tidak signifikan mempengaruhi financial distress .

Kata kunci: financial distress, likuiditas, profitabilitas, inflasi, dan kurs.

\section{ABSTRACT}

This study aims to determine the prediction of financial distress in the manufacturing industry sub-sector food and beverage listed on the Indonesia Stock Exchange. The research period is 2011-2015. In this study, using the indicator liquidity, profitability, inflation, and exchange rates. The study population includes all sub-sectors of food and beverages listed on the Indonesia Stock Exchange 20112015 period. The sample is determined by purposive sampling technique. Data analysis method used is logistic regression analysis.

The results showed that the current ratio, return on investment and the net profit margin, and the inflation rate is the most significant variable in predicting financial distress, while the exchange rate is the only variable that was not significant in influencing financial distress.

Keywords: financial distress, liquidity, profitability, inflation, and exchange rates.

\section{PENDAHULUAN}

Indonesia merupakan salah satu negara yang mendapat dampak dari goncangan krisis ekonomi ini. Hal ini nampak pada delisting 20 saham perusahaan yang terdaftar di BEI (www.sahamok.com). Perusahaan tersebut pada umumnya mengalami kesulitan keuangan yang sering disebut dengan istilah financial distress. Ketika masalah financial distress tersebut tidak mampu diselesaikan oleh perusahaan, maka perusahaan tersebut akan mengalami kebangkrutan. Salah satu faktornya meliputi penurunan kinerja perusahaan yang ditandai dengan ketidakcukupan modal, besarnya beban utang, dan bunga. Perusahaan yang terus menunjukkan kinerja yang menurun dikhawatirkan mengalami kondisi financial distress yang berujung pada kebangkrutan perusahaan.

Rasio likuiditas merupakan kemampuan perusahaan memenuhi kewajiban jangka pendeknya. Semakin tinggi tingkat likuiditas sebuah organisasi perusahaan, maka semakin baik pula kinerja perusahaan tersebut. Sebaliknya, semakin rendah tingkat likuiditas sebuah organisasi perusahaan, maka semakin buruk kinerja perusahaan tersebut. Perusahaan yang memiliki tingkat likuiditas yang tinggi akan lebih berpeluang mendapatkan berbagai macam dukungan dari pihak-pihak luar seperti lembaga keuangan, kreditur, dan juga pemasok bahan baku. Rasio selanjutnya yaitu profitabilitas. Profitabilitas merupakan salah satu pengukuran bagi kinerja suatu perusahaan, karena profitabilitas suatu perusahaan menunjukan kemampuan suatu perusahaan dalam menghasilkan laba selama periode tertentu pada tingkat penjualan, asset dan modal saham tertentu. Profitabilitas suatu perusahaan dapat dinilai melalui berbagai cara tergantung pada laba dan aktiva atau modal yang akan diperbandingkan satu dengan lainya. Profitabilitas juga mempunyai peranan penting dalam mempertahankan kelangsungan hidup 
perusahaan dalam jangka panjang, karena profitabilitas menunjukan apakah badan usaha tersebut mempunyai prospek yang baik dimasa yang akan datang. Dengan demikian setiap badan usaha akan selalu berusaha meningkatkan profitabilitasnya, karena semakin tinggi tingkat profitabilitas suatu badan usaha maka kelangsungan hidup badan usaha tersebut akan lebih terjamin.

Dalam menilai kinerja keuangan juga perlu memperhatikan variabel makro yaitu inflasi dan kurs. Inflasi diartikan sebagai kenaikan yang menyeluruh dari jumlah uang yang harus dibayarkan terhadap barang-barang dan jasa (Karim 2010;135). Kenaikan harga dari satu atau dua barang saja tidak dapat disebut inflasi kecuali bila kenaikan itu meluas (atau mengakibatkan kenaikan harga) pada barang lainnya. Kebalikan dari inflasi disebut deflasi (www.bi.go.id).

Kurs (exchange rate) adalah harga sebuah mata uang dari suatu negara yang diukur atau dinyatakan dalam mata uang lainnya (www.bi.go.id). Menurut Karim (2010;157). Nilai kurs sangat penting saat mengambil keputusan untuk berbelanja atau membeli barang dari luar negeri, karena dengan kurs kita akan menerjemahkan harga-harga barang dari berbagai macam negara kedalam mata uang negara kita. Kurs disebut juga sebagai perbandingan nilai dalam pertukaran mata uang berbeda. Jadi terdapat perbandingan nilai diantara kedua mata uang tersebut, dan perbandingan inilah yang disebut dengan kurs. Jika harga kurs atau harga valuta asing naik pada suatu negara, maka biasanya akan menyebabkan harga barang yang di inport menjadi lebih mahal, jika mengalami penurunan maka harga barang yang di import biasanya akan murah.

Menggunakan financial distress sebagai variabel dependen karena financial distress merupakan salah satu faktor yang dapat mengetahui kondisi keuangan perusahaan. Dengan mengetahui financial distress diharapkan perusahaan dapat melakukan tindakan-tindakan yang bertujuan untuk mengantisipasi perusahaan ke arah kebangkrutan. Mengetahui financial distress dengan menilai kinerja keuangan perusahaan dengan menganalisis laporan keuangannya maka dapat dijadikan informasi untuk menanamkan modalnya bagi investor baru dan dijadikan informasi untuk menahan atau melepas investasinya bagi investor lama. Bagi perusahaan, informasi mengenai kinerja keuangan perusahaan tersebut dapat dijadikan acuan untuk menilai perusahaan dan dalam pemenuhan pengambilan keputusan, serta untuk rencana perbaikan perusahaan di masa yang akan datang.

\section{Rumusan Masalah}

1. Apakah likuiditas berpengaruh terhadap financial distress?

2. Apakah profitabilitas berpengaruh terhadap financial distress?

3. Apakah inflasi berpengaruh terhadap financial distress?

4. Apakah nilai kurs berpengaruh terhadap financial distress?

5. Apakah likuiditas, profitabilitas, inflasi, dan kurs berpengaruh secara simultan terhadap financial distress?

\section{Tujuan Penelitian}

1. Untuk mengetahui pengaruh likuiditas terhadap financial distress.

2. Untuk mengetahui pengaruh profitabilitas terhadap financial distress.

3. Untuk mengetahui pengaruh inflasi terhadap financial distress.

4. Untuk mengetahui pengaruh kurs terhadap financial distress.

5. Untuk mempengaruh pengaruh secara simultan likuiditas, profitabilitas, inflasi, dan kurs terhadap financial distress.

\section{KAJIAN PUSTAKA}

Menurut Sudana $(2009 ; 261)$ suatu perusahaan tidak selalu berkembang dengan baik sebagaimana yang diharapkan. Karena dalam prakteknya, banyak perusahaan dapat mengalami kegagalan. Adapun faktor yang dapat menyebabkan perusahaan mengalami kegagalan, diantaranya adalah: faktor ekonomi, kesalahan manajemen, bencana alam. Perusahaan yang mengalami kegagalan dalam operasinya, akan berdampak pada kesulitan keuangan (financial distress). Kesulitan keuangan yang dihadapi oleh perusahaan sangat bervariasi antara kesulitan likuiditas hingga kesulitan solvabilitas. Apabila prospek perusahaan kurang baik, maka perusahaan dapat dilikuidasi.

Menurut Hery $(2014 ; 3)$ laporan keuangan merupakan produk akhir dari serangkaian proses pencatatan dan pengikhtisaran data-data transaksi bisnis. Laporan keuangan pada dasarnya adalah hasil dari proses akuntansi yang dapat digunakan sebagai alat untuk mengkomunikasikan data 
keuangan atau aktivitas perusahaan kepada pihak-pihak yang berkepentingan. Dalam mengukur kinerja keuangan dapat dilakukan dengan beberapa variabel, diantaranya menggunakan rasio keuangan, tingkat inflasi dan kurs. Menurut Fahmi $(2012 ; 49)$ rasio keuangan adalah suatu kajian yang melihat perbandingan antara jumlah-jumlah yang terrdapat pada laporan keuangan dengan mempergunakan formula-formula yang dianggap representif untuk ditetapkan. Ada lima jenis rasio keuangan, yaitu rasio likuiditas, rasio aktivitas, rasio leverage, rasio profitabilitas, dan rasio pasar

Selain itu variabel yang dapat digunakan dalam menilai kinerja keuangan yaitu dengan inflasi dan kurs. Inflasi sebagai kenaikan yang menyeluruh dari jumlah uang yang harus dibayarkan terhadap barang-barang dan jasa (Karim 2010;135). Kenaikan harga dari satu atau dua barang saja tidak dapat disebut inflasi kecuali bila kenaikan itu meluas (atau mengakibatkan kenaikan harga) pada barang lainnya. Kebalikan dari inflasi disebut deflasi (www.bi.go.id).

Kurs (exchange rate) adalah harga sebuah mata uang dari suatu negara yang diukur atau dinyatakan dalam mata uang lainnya (www.bi.go.id). Menurut Sukirno (2010;397) kurs valuta asing menunjukkan harga atau nilai mata uang suatu negara dinyatakan dalam nilai mata uang negara lain. Kurs adalah catatan harga pasar dari mata uang asing dalam harga mata uang domestik dalam mata uang asing. Kurs dapat ditentukan oleh pemerintah (otoritas moneter) seperti pada negara-negara yang memakai sistem kurs tetap ataupun ditentukan oleh kombinasi antara kekuatan-kekuatan pasar yang saling berinteraksi (bank komersial, perusahaan multinasional, perusahaan manajemen asset, perushaaan asuransi, bank devisa dan bank sentral) serta kebijakan pemerintah seperti pada negara-negara yang memakai rezim sistem "kurs yang fleksibel" (Karim, 2010;157).

\section{Hipotesis}

\section{Pengaruh Current Ratio terhadap kondisi financial distress}

Menurut penelitian Kariman (2016), Rusaly (2016), dan Widati dan Pratama (2015) menyatakan bahwa current ratio tidak berpengaruh terhadap financial distress. Menurut penelitian Marwati (2011) dan Putra (2009) bahwa current ratio berpengaruh positif terhadap financial distress.

H1: Diduga likuiditas berpengaruh terhadap kondisi financial distress perusahaan.

2. Pengaruh profitabilitas terhadap kondisi financial distress

Penelitian Kariman (2016), Widati dan Pratama (2015) menyatakan bahwa profitabilitas berpengaruh positif terhadap financial distress. Artinya semakin besar profitabilitas suatu perusahaan semakin mengurangi kondisi financial distress perusahaan tersebut dan rasio yang paling dominan dalam memprediksi kondisi financial distress adalah rasio profitabilitas. Sedangkan menurut Rusaly (2016), Marwati (2011), dan Putra (2009) menemukan profitabilitas berpengaruh negatif terhadap financial distress.

H2: Diduga profitabilitas berpengaruh terhadap kondisi financial distress perusahaan.

3. Pengaruh inflasi terhadap kondisi financial distress

Penelitian yang dilakukan oleh Rahmidani (2013) menunjukan bahwa indikator makro ekonomi tidak berpengaruh secara signifikan terhadap financial distress. Meningkatnya inflasi yang ditandainya dengan meningkatnya harga-harga akan berpengaruh terhadap kondisi keuangan perusahaan, karena perusahaan harus menambah biaya untuk pembelian bahan produksi, sedangkan perusahaan tidak bisa langsung menaikkan harga jual karena bisa berdampak terhadap penjualan produk.

H3: Diduga tingkat inflasi berpengaruh positif terhadap kondisi financial distress.

4. Pengaruh kurs terhadap kondisi financial distress

Pada penelitian Utami (2014) menemukan bahwa kurs US\$ terhadap rupiah memiliki pengaruh yang signifikan terhadap peningkatan probabilitas perusahaan non keuangan mengalami financial distress. Sedangkan penelitian yang dilakukan oleh Rahmidani (2013) menunjukan bahwa indikator makro ekonomi tidak berpengaruh secara signifikan terhadap financial distress.

H4: Diduga kurs berpengaruh positif terhadap kondisi financial distress. 
Jenis penelitian ini adalah penelitian asosiatif kausal. Penelitian asosiatif kausal adalah untuk mengetahui pengaruh antar variabel yang dihipotesiskan (Indriantoro dan Supomo, 2014:27). Sampel penelitian adalah industri manufaktur sub sektor makanan dan minuman yang terdaftar di Bursa Efek Indonesia (BEI).

\section{HASIL PENELITIAN \\ PEMBAHASAN}

DAN

\section{1) Analisis Regresi logistik}

Regresi logistik adalah regresi yang digunakan untuk menguji apakah probabilitas terjadi variabel terikat dapat diprediksi dengan variabel bebasnya (Ghozali, 2016;321). Berdasarkan hasil analisis regresi logistik yang telah dilakukan dengan menggunakan program spss (Statistical Product dan Service Solutions) release 16,00 for windows didapatkan hasil perhitungan sebagai berikut:

\section{Tabel 1}

\section{Regresi Logistik Variables in the Equation}

\begin{tabular}{|c|c|c|c|c|c|c|}
\hline & B & SE. & Wald & $\mathrm{Df}$ & Sig. & $\operatorname{Exp}(B)$ \\
\hline Step $1^{2}$ LikujdilasX1 & .105 & .269 & .152 & 1 & .027 & 1.110 \\
\hline ProfitabilitsX2 & 1.695 & 2.0000 & .658 & 1 & .017 & .184 \\
\hline InflasiX3 & 41.739 & 226.4133 & .034 & 1 & .044 & 1.340 \\
\hline KursX4 & 226 & 1.196 & .036 & 1 & 850 & 1.253 \\
\hline Coustant & 24.294 & 130.075 & .035 & 1 & .852 & .000 \\
\hline
\end{tabular}

\section{Uji Hipotesis}

1) Pengaruh likuiditas terhadap financial distress

Berdasarkan hasil pengujian regresi yang diperoleh koefisien likuiditas yang menunjukkan positif. Ini berarti likuiditas berpengaruh positif terhadap financial distress. Jika dilihat dari nilai signifikansi 0,27 yaitu dibawah nilai 0,05. Dapat disimpulkan bahwa likuiditas berpengaruh terhadap financial distress. Hal ini dikarenakan pada saat jatuh tempo perusahaan tidak memiliki kecukupan dana secara tunai untuk memenuhi kewajiban jangka pendeknya sehingga harus menunggu dalam waktu tertentu untuk mencairkan aktiva lainnya, seperti menagih piutang, menjual surat-surat berharga, atau menjual sediaan atau aktiva lainnya. Likuiditas digunakan untuk mengungkapkan jaminan keamanan

(margin safety) perusahaan terhadap kreditor jangka pendek. Jika perbandingan utang lancar melebihi aktiva lancarnya, maka perusahaan dikatakan mengalami kesulitan melunasi utang jangka pendeknya. Jika rasio likuiditas terlalu tinggi, maka sebuah perusahaan dikatakan kurang efisien dalam mengurus aktiva lancarnya. Sesuai dengan teori yang dikemukakan oleh Fahmi (2012;66) mengatakan bahwa jika kewajiban lancar meningkat lebih cepat dibandingkan aktiva lancar, maka rasio lancar akan turun dan hal ini bisa menimbulkan permasalahan, maka dapat dimungkinkan bahwa pola hubungan antara likuiditas dengan probabilitas kebangkrutan adalah negatif.

Hasil ini sesuai dengan dengan penelitian yang dilakukan oleh Putra (2009) yang menyatakan bahwa Hal ini dikarenakan bahwa pada perusahaan sampel perusahaan memiliki kemampuan mendanai operasional perusahaan dalam memenuhi kewajiban (hutang) jangka pendek dengan hutang lancar yang dimilikinya. Namun ini tidak sesuai dengan penelitian yang dilakukan oleh Kariman (2016), dan Rusaly (2016) yang menyatakan bahwa current ratio memiliki pengaruh negatif terhadap financial distress. Semakin kecil rasio ini maka semakin kecil aktiva yang dapat digunakan untuk kegiatan operasional perusahaan, sehingga probabilitas perusahaan mengalami kondisi financial distress semakin besar.

2) Pengaruh profitabilitas terhadap financial ditress

Berdasarkan hasil pengujian regresi yang diperoleh koefisien profitabilitas yang menunjukkan positif. Ini berarti profitabilitas berpengaruh positif terhadap financial distress. Jika dilihat dari nilai signifikansi sebesar 0,017 yakni dibawah 0,05. Dapat disimpulkan bahwa profitabilitas berpengaruh terhadap financial distress. Karena manajemen perusahaan tidak mampu mencapai target yang telah ditetapkan. Sehingga perusahaan memperoleh laba yang kecil, yaitu lebih besar kewajibannya dibanding laba yang diperolehnya. Hal ini dapat dijadikan pelajaran bagi manajemen perusahaan untuk ke depannya. Kegagalan ini harus diselidiki dimana letak kesalahan dan kelemahannya sehingga kejadian tersebut tidak akan terulang. Kemudian, kegagalan atau keberhasilan dapat dijadikan 
sebagai bahan acuan untuk perencanaan laba ke depan. Hal ini sesuai dengan teori yng dikemukakan oleh Fahmi (2012;80) menyatakan bahwa profitabilitas merupakan kemampuan perusahaan memperoleh laba dari sumber-sumber yang dimiliki.

Hasil ini sesuai dengan penelitian yang dilakukan oleh Kariman (2016) menyatakan bahwa profitabilitas berpengaruh terhadap financial distress. Profitabilitas yang tinggi menunjukkan perusahaan mampu menggunakan asset dan investasi yang dimiliki untuk menghasilkan laba, sehingga semakin efektif dan efisien pengelolaan aktiva perusahaan dapat mengurangi biaya yang dikeluarkan perusahaan. Hasil ini tidak mendukung penelitian dari Putra (2009) yang menyatakan profitabilitas tidak berpengaruh terhadap financial distress. Apabila profitabilitas tinggi menunjukkan kemampuan aktiva perusahaan kurang produktif menghasilkan laba, dan kondisi seperti ini akan mempersulit keuangan perusahaan dalam sumber pendanaan internal untuk investasi, sehingga dapat menyebabkan financial distress.

3) Pengaruh inflasi terhadap financial distress Berdasarkan hasil pengujian regresi yang diperoleh koefisien inflasi yang menunjukkan positif. Ini berarti inflasi berpengaruh positif terhadap financial distress. Berdarkan tabel 4.7 dengan nilai signifikansi 0,044. Dapat disimpulkan bahwa inflasi berpengaruh terhadap financial distress. Hal ini dikarenakan uang yang beredar semakin banyak, maka permintaan barang dan jasa semakin meningkat. Yang mengakibatkan hargaharga cenderung naik, ini sesuai dengan hukum ekonomi, jika permintaan naik sedangkan penawaran tetap maka harga cenderung naik. Yang mengakibatkan perusahaan membutuhkan dana lebih untuk memenuhi permintaan tersebut. Karena perusahaan tidak memiliki kecukupan dana untuk memenuhi kegiatan operasionalnya maka perusahaan mengalami kesulitan keuangan untuk memenuhinya, yang kemudian melakukan pinjaman kepada pihak ketiga. Hal ini sesuai dengan teori yang dikemukakan oleh Karim $(2010 ; 135)$ yang menyatakan bahwa inflasi merupakan kenaikan yang menyeluruh dari jumlah uang yang harus dibayarkan terhadap barangbarang dan jasa.

Hasil ini sesuai dengan penelitian yang dilakukan oleh Utami (2014) yang menyatakan inflasi berpengaruh terhadap financial distress, karena tingkat inflasi tinggi, ini sangat berpengaruh terhadap kegiatan operasional perusahaan, karena semakin banyak biaya yang dikeluarkan oleh perusahaan, yang dikarenakan adanya kenaikan pada harga bahan baku. Namun bertolak belakang dengan hasil penelitian yang dilakukan oleh Rahmidani (2013) yang menyatakan inflasi tidak berpengaruh terhadap financial distress, karena inflasi akan berpengaruh terhadap harga barang dan akan bepengaruh terhadap kemampuan konsumen untuk membeli barang dan selanjutnya akan menurunkan omset penjualan perusahaan.

4) Pengaruh kurs terhadap financial ditress Berdasarkan hasil pengujian regresi yang diperoleh koefisien kurs yang menunjukkan negatif. Ini berarti kurs berpengaruh negatif terhadap financial distress. Jika dilihat dari nilai signifikansi 0,850. Dapat disimpulkan bahwa kurs tidak berpengaruh terhadap financial distress. Hasil penelitian ini mencerminkan bahwa indikator makro ekonomi yaitu rata-rata nilai kurs yang mungkin banyak mengalami peningkatan pada tahun 20115, dan 2014, dari pada tahun 2013, 2012 dan 2011 masih dapat digolongkan dalam kondisi ekonomi yang relatif terjaga kestabilannya, karena pemerintah masih bisa mengontrol nilai kurs dengan mengeluarkan kebijakan agar nilai kurs tidak merosot terlalu tajam, sehingga perubahan kondisi ekonomi ini tidak terlalu berdampak bagi keadaan perusahaan sub sektor makanan dan minuman. Ini sesuai dengan teori yang dikemukakan oleh Sukirno $(2010 ; 397)$ yang menyatakan bahwa kurs valuta asing menunjukkan harga atau nilai mata uang suatu negara dinyatakan dalam nilai mata uang negara lain.

Hasil ini sesuai dengan penelitian yang dilakukan oleh Rahmidani (2013) yang menyatakan kurs tidak berpengaruh terhadap financial distress, karena tidak terlalu banyak perusahaan yang menggunakan pinjaman dalam bentuk mata uang asing dan menggunakan bahan baku impor. Hasil ini bertolak belakang dengan hasil penelitian yang dilakukan oleh Utami (2014) yang 
menyatakan bahwa kurs berpengaruh positif terhadap financial distress, karena nilai tukar akan berpengaruh hanya pada perusahaan yang menggunakan utang \&lam mata uang asing dan perusahaan yang mengandalkan bahan baku impor.

Dari hasil perhitungan yang dilakukan menunjukkan terdapat 3 variabel yang nilainya dibawah signifikansi yaitu likuiditas, profitabilitas, inflasi, dan kurs. Dan kurs memiliki nilai diatas signifikansi. Hal tersebut berarti nilai signifikansi model lebih kecil dengan nilai signifikansi alpha (5\%) sehingga Ha terbukti, yang berarti bahwa likuiditas, profitabilitas, dan inflasi berpengaruh signifikan terhadap financial distress. Dengan demikian dapat dikatakan bahwa hipotesis pertama diterima yang menyatakan 3 variabel bebas tersebut berpengaruh signifikan terhadap financial distress. Hal ini menjadikan bertolak belakang dengan penelitian yang dilakukan oleh Kariman (2016), dan Rusaly (2016) yang menyatakan bahwa current ratio memiliki pengaruh negatif tehdap financial distress.

Sedangkan untuk mengetahui variabel yang paling besar memberikan kontribusi terhadap financial distress dilakukan dengan membedakan nilai korelasi parsial (R) masing-masing variabel dengan nilai korelasi parsial variabel bebas tersebut dikarenakan terdapat 3 variabel yang signifikan dan diketahui bahwa profitabilitas memberikan kontribusi terbesar terhadap financial distress. Dengan demikian dapat dikatakan bahwa hipotesis kedua diterima sesuai dengan hasil penelitian yang dilakukan oleh Kariman (2016) yang menyatakan profitabilitas berpengaruh positif terhadap financial ditress.

Namun kurs tidak berpengaruh secara signifikan terhadap financial distress. Hal ini menandakan bahwa peningkatan danpenurunan nilai kurs tidak berpengaruh besar terhadap perusahaan. Yang dibuktikan dengan hasil perhitungan dengan alat analisis deskriptif, regresi logistik, dan uji hipotesis menggunakan Aplikasi SPSS yaitu dengan beberapa nilai yang didapatkan pada variabel bebas tersebut. Hal ini dikarenakan nilai signifikansi dari masing-masing variabel pada variabel bebas menunjukkan nilai yang bervariasi terdapat variabel likuiditas, profitabilitas, dan inflasi dibawah signifikansi alpha.

Simpulan dan Saran

1. Variabel likuiditas yang diukur dengan current ratio (CR) berpengaruh positif terhadap financial distress

2. Variabel profitabilitas yang diukur dengan return on investment dan net profit margin berpengaruh positif terhadap financial distress

3. Variabel inflasi berpengaruh positif terhadap financial distress

4. Variabel kurs berpengaruh negatif terhadap financial distress

Penelitian ini menguji kinerja keuangan dalam memprediksi financial distress, maka disarankan bagi perushaan sebaiknya memprediksi financial distress sebagai peringatan dini, untuk menghindari kebangkrutan. Sehingga jika perusahaan mengalami financial distress maka pihak manajemen dapat melakukan berbagai rencana untuk dijadikan strategi peningkatan kualitas perusahaan dimasa yang akan dating.

\section{DAFTAR PUSTAKA}

1. Arikunto, S. 2010. Prosedur Penelitian: Suatu Pendekatan Praktik (Edisi Revisi). Jakarta: Rineka Cipta.

2. Daft, Richard L. 2010. Manajemen. Jakarta: Salemba Empat.

3. Djumahir. 2007. Pengaruh VariabelVariabel Mikro Dan Variabel-Variabel Makro Terhadap Financial Distress Pada Perusahaan Industri Food And Beverage Yang Terdaftar DI Bursa Efek Jakarta. Jurnal Ilmu Ekonomi.

4. Fahmi, Irham. 2013. Pengantar Manajemen Keuangan. Bandung: Alvabeta, CV.

5. Fitriyah, Ida dan Hariyati. 2013. Pengaruh Rasio Keuangan Terhadap Financial Distress Pada Perusahaan Properti Dan Real Estate. Jurnal Ilmu Manajemen.

6. Ghozali, Imam. 2016. Aplikasi Analisis Multivariete Dengan Program IBM SPSS 23. Semarang: Badan Penerbit Universitas Diponegoro.

7. Hanafi, Mamduh. 2015. Manajemen Keuangan. Yogyakarta: BPFEYogyakarta.

8. Handoko, T. Hani. 2012. Manajemen. Yogyakarta: BPFE-Yogyakarta.

9. Hery. 2012. Analisis Laporan Keuangan. Jakarta: PT. Bumi Aksara. 
10. Harahap, Sofyan Syafri. 2009. Analisis Kritis Atas Laporan Keuangan. Jakarta: Raja Grafindo Persada.

11. Karim, Adiwarman A. 2010. Ekonomi Makro Islam. Jakarta: PT. Grafindo Persada.

12. Kariman, Roziqon. 2016. Prediksi Financial Distress Dengan Menggunakan Multiple Descriminant Pada Perusahaan Yang Terdaftar Di Burs Efek Indonesia.Yogyakat: Progra Sarjana Universitas Negeri Yogyakarta.

13. Nugroho, Yohanes Anton, 2011, Olah Data Dengan SPSS. Cetakan Pertama. Yogyakarta: Skripta Media Creative.

14. Marwati, Dian. 2011. Analisis Rasio Keuangan Dalam Memprediksi Financial Distress Pada Perusahaan Manufaktur Yang terdaftar Di BEI. Jurnal Ilmu ekonomi.

15. Priyatno, Duwi. 2010. Teknik Mudah Dan Cepat Melakukan Analisis Data Penelitian Dengan SPSS Dan Tanya Jawab Ujian Pendadaran.Yogyakarta: Gava Media.

16. Putra, Satriyadi. 2009. Analisis Rasio keuangan Dalaman Memprediksi Financial Distress Pada Perusahaan Manufaktur Yang Terdaftar DI BEI. Surakarta: Universitas Sebelas Maret.

17. Rahmidani, Rose. 2013. Pengaruh Inflasi, Suku Bunga, Dan Nilai Tukar Terhadap Financial Distress. Jurnal Ilmu Ekonomi.

18. Rusaly, Adila. 2016. Pengaruh Likuiditas Dan Profitabilitas Terhadap Financial Distress Pada Perusahaan Transportasi Yang Terdaftar Di BEI Tahun 2010-2014. Makassar: Universitas Hasanuddin Makassar.

19. Sarwono, Jonathan. 2009. Statistik Itu Mudah, Panduan Lengkap Untuk Belajar Komputasi Statistik Menggunakan SPSS 16. Yogyakarta: Penerbit Andi.

20. Sudana, I Made. 2009 Manajemen Keuangan Teori Dan Praktik. Surabaya: Airlangga University Press.

21. Sugiyono. 2009. Metode Penelitian Bisnis (Pendekatan Kuantitatif, Kualititaif Dan R\&D). Bandung: Alfabeta.

22. Sukirno, Sadono. 2010. Makro Ekonomi Teori Pengantar. Jakarta: PT. Rajagrafindo Persada.
23. Sule, Ernie T dan Kurniawan S. 2014. Pengantar Manajemen. Jakarta: Prenadamedia Group.

24. Supomo, Bambang dan Nur Indriantoro. 2014. Metodologi Penelitian Bisnis Untuk Akuntansi dan Manajamen. Yogyakarta: BPFE-Yogyakarta.

25. Widati, Listyorini dan Bayu Adhi Pratama. 2015. Pengaruh Current Ratio, Debt To Equity Ratio, Return On Equity, Untuk Memprediksi Financial Distress. Jurnal Ilmu Ekonomi.

26. www.bei.co.id.

27. www.idx.co.id.

28. wwW.sahamok.co.id

29. www.bi.go.id 